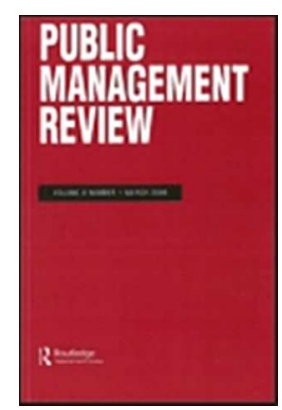

\title{
A typology for the relationship between local governments and NPOs in welfare state regimes: the Belgian case revisited
}

\begin{tabular}{|r|l|}
\hline Journal: & Public Management Review \\
\hline Manuscript ID: & RPXM-2012-0090.R2 \\
\hline Manuscript Type: & Article \\
\hline Keywords: & $\begin{array}{l}\text { Nonprofit organizations, Local Government, Government-nonprofit } \\
\text { relationships, Policy implementation, Welfare state }\end{array}$ \\
\hline
\end{tabular}

\section{SCHOLARONE ${ }^{\text {m }}$}

Manuscripts 


\section{A typology for the relationship between local governments and NPOs in welfare state regimes: the Belgian case revisited}

\section{Introduction and research topic}

Nonprofit organizations (NPOs) perform a variety of roles in contemporary societies. In addition to their role in social welfare provision, NPOs are also involved in the development of public policies, and they may give a voice to the interests of their clients, or have a stake in the creation of social capital (Putnam 1995; Ross and Osborne 1999; Salamon, Anheier et al. 1999; Snavely and Desai 2001; Anheier 2005; Schneider 2009; Balassiano and Chandler 2010). An important issue in current nonprofit research is about the understanding of the relations these private nonprofit actors develop with government, especially given the trend towards increased cooperation and financial ties between NPOs and governments in many modern welfare states (Smith and Lipsky 1993; Salamon, Sokolowski et al. 2004). As Najam (2000) puts it, NPOs hereby function as policy entrepreneurs which make their way through different stages of the policy cycle. Due to their initial social mission, NPOs are equally driven by a desire to defend the interests of their constituents and clients and to advocate for social change. In this process, the resources, goals, interests and priorities of the NPOs and governments inevitably will collide, sometimes in harmony, sometimes in discord. It is argued that the nature and conditions of this interaction will shape the NPO-government relationships that emerge. In that respect there is a tension, that can't be ignored nor camouflaged, between these actors as they both float through the same policy stream (Najam 2000). In order to capture these tensions scholars have developed ideal-typical typologies or frameworks through which these interactions could be analyzed along different relational dimensions with the purpose of locating nation-states within various descriptive or explanatory groupings (Kuhnle and Selle 1990; Coston 1998; Najam 2000; Young 2000; Brinkerhoff 2002; McLaughlin 
and Osborne 2003; Vincent and Harrow 2005; Dörner 2008; Zimmer 2010). Still, these typologies have been rarely subject to empirical testing (Vincent and Harrow 2005).

With this study, we hope to contribute to the understanding of the nature of the relationships NPOs and local governments have developed. We will apply the typology originally developed by Kuhnle and Selle (1990) in Flanders, the Dutch speaking region of Belgium. Our analysis will be based on survey-data, from a questionnaire that was completed by more than 200 Belgian NPO executives. Although, historically spoken, many of these NPOs have established tight boundaries with the regional Flemish government (e.g. in terms of financing), we recently witnessed a tendency to increase the role of local governments in steering these private nonprofit organizations. Therefore, the main focus of this article will be on the relationships between local governments and NPOs.

Our study has two main objectives. Firstly: measuring the features of the specific relations NPOs develop with local government, and systematizing these by making use of a conceptual typology. This will allow us to understand these relationships, and to feedback empirical reality to typologies. Secondly, our study also has some policy-relevance. Based on our data, we should be able to add to the discussion about the extent to which regulation that is imposed by central government, is actually implemented at the local level. Flemish government recently launched the Decree on Local Social Policy (2004), by which the Flemish government explicitly asks local governments, as being the closest level to citizens, to increase their interactions with private nonprofit suppliers that are active on their territory with the purpose of maximizing accessibility of basic social service delivery to the largest amount of citizens (Verschuere and Rynck 2010). Thus, based on our research, we will be able to assess the extent to which empirical reality (the perception of NPOs about their relations with local government) offers fertile 
ground to implement the ideas of the Decree on Local Social Policy (increasing and formalizing NPO local government cooperation).

This article will be structured as follows. We will first outline the research context: the Flemish welfare state, as an example of the cluster of continental European welfare states, and the regulatory framework in which local government - NPO relationships develop in Flanders: the Decree on Local Social Policy. Secondly, we review the literature on government-nonprofit relationships, and select a concept that is relevant for our research purposes. Thirdly, we discuss our research method. Fourthly, the results of our analysis will be presented. Finally, we conclude with a discussion in which we will elaborate on this article's dual objective by adding to the debate on the nature of the relationships between governments and NPOs in a modern welfare regime, and by discussing the circumstances under which top-down policy initiatives, aiming at increasing and formalizing this cooperation, can be implemented in reality.

\section{The research context: the Flemish welfare state, local social policy and government - NPO relations}

As governments in many contemporary welfare states increasingly interact with private nonprofit organizations to deliver social services, the nonprofit sector has become an essential part of the 'welfare-mix', made of shared responsibilities among various types of service providers (Salamon, Anheier et al. 1999; Defourny and Pestoff 2008). This has also been the case under the 'third-party government' regime as it was established in the aftermath of the Second World War in Belgium. The importance of this nonprofit sector is clear: its activities represent approximately $10 \%$ of the GDP and the nonprofit workforce is the equivalent of 359.000 full-time jobs (Defourny and Pestoff 2008). In relative terms, the nonprofit sector under study in this article even is amongst the largest in the world 
(Salamon, Anheier et al. 1999). Overall, these NPOs nowadays receive more than half of their total income from public resources to fulfill their role, as so-called 'third parties' on behalf of government, in public welfare provision (Salamon 1987; De Rynck, Verschuere et al. 2009). Although most Belgian NPOs have historically been recognized, financed and steered by the regional Flemish government, the role and impact of local governments towards these NPOs may not be overlooked (Salamon, Anheier et al. 1999; Anheier 2005; De Rynck, Verschuere et al. 2009). This could be especially the case in major Flemish cities, in which local governments have always been involved, to some or lesser extent, in dayto-day interaction with these private actors active on their territory.

With the recent Decree on Local Social Policy (2004) Flemish government specifically aims at increasing and formalizing these public-private interactions at the local level. Local governments have a coordinating role in mapping the supply of social welfare services on their territory in a more systematic way and to attune service delivering efforts of all actors involved. Hence, local governments are expected to maintain direct contacts with these actors and formally involve them in the development of local social policies.

\section{Literature review: the relationship between governments and NPOs}

Several dimensions of the relationship between governments and NPOs have been highlighted in the nonprofit literature. In a general sense, Anheier (2005) distinguishes between funding (grants, fee-forservice contracts, etc), non-monetary support (facilities, expertise, etc), mandates (government required to involve nonprofit associations in implementing policy) and regulations and accountability. However, the meaning and magnitude of these relationships differ by type of organization (large charities versus small local associations), field (social services versus international development) and levels of 
government involved (federal versus local or regional) (Anheier 2005). From the perspective of the NPOs service delivery role, it has been argued that the relationship between these NPOs and governments (for example with the purpose of implementing social policies) is most directly embodied by the funding streams and the control measures attached to these funds (Toepler 2010; Suarez 2011). The financial ties between governments and the nonprofit sector have been studied in the John Hopkins Comparative Nonprofit Sector Project. It was found that, especially in Western countries, public funding is a very important income source, representing a significant share, and in some cases even more than half, of the NPOs total budget (Salamon, Anheier et al. 1999). Furthermore, a substantial amount of literature focuses on the accountability requirements attached to these public funds and the processes through which governments try to exert control over these non-public actors involved in public service delivery (Ospina, Diaz et al. 2002; Whitaker, Altman-Sauer et al. 2004; May 2007; VanSlyke 2007; Benjamin 2008).

Although most NPOs primarily focus on delivering services, often (but not always) in collaboration with the state, they also perform other roles in civil society (Anheier 2005). Nonprofit organizations could for example engage in advocacy work or could have a stake in the formulation and development of new policies, by translating issues into political claims that can be defended by maintaining direct contacts or open lines of communication with policy makers (Kramer 1981; Salamon 1995; Ross and Osborne 1999; Salamon, Anheier et al. 1999; Snavely and Desai 2001; Sawer 2002; Binderkrantz 2005; Balassiano and Chandler 2010; Mosley 2011). Furthermore, NPOs are also playing a role in the creation of social capital in societies. By bringing people together to interact, to learn more about each other, to collaborate in activities and to voice opinions, they build up a repository of trust and norms of reciprocity, meaning that they are obligated to promote their common interests (Putnam 1995; Putnam 2000). 
International scholarship on the interaction between governments and nonprofit organizations has however not been limited to a mere description of some relational dimensions. Some recent studies specifically focused on the management of those partnerships and its impact on potential outcomes (Wang 2006; Gazley 2010; Klijn, Steijn et al. 2010; Mandell and Keast 2011; Amirkhanyan, Kim et al. 2012). In the last decade many scholars tried to develop typologies of government-nonprofit interactions based on a combination of at least two dimensions. Such typologies proved to be excellent frameworks to capture some of the systematic variations in government-NPO relationships into idealtypical categories. Amongst the most cited typologies are for example the 4C's model of Adil Najam (2000), the complementary, supplementary and adversarial lenses of Dennis Young (2000), the work of McLaughlin and Osborne on community governance in the UK (2003); and the refinement of government-NPO partnerships by Jennifer Brinkerhoff (Najam 2000; Young 2000; Brinkerhoff 2002; McLaughlin and Osborne 2003). A particularly interesting framework, for the purposes of our study, was developed by Stein Kuhnle and Per Selle (1990) in order to study the nature of the government-NPO relationships in their home country Norway. Their framework and its particular dimensions proved to be very relevant to study government-NPO relationships in the context of welfare regimes. It can for example allow us to study the 'one-on-one' relationships between local governments and individual organizations as units of analysis. Furthermore, our dataset of more than 200 Flemish NPO executives contains several variables through which key dimensions of this typology, such as 'contact', 'financing' and 'control' could be measured. Kuhnle and Selle's framework can also be helpful to put our findings into a comparative perspective, as this typology has recently been applied by other scholars doing research in other countries like Scotland, England, Denmark and Slovenia (Vincent and Harrow 2005; Henriksen 2007; Kolaric and Rakar 2007). 
Stein Kuhnle and Per Selle (1990) conceptualized the relationship between government and NPO along the dimensions of 'closeness' (or distance) between both actors, and the independence (or autonomy) of the nonprofit organizations from government. The first dimension ('closeness') refers to the scope, the frequency and the easiness with which communication between both actors occurs. Organizations may thus be more near in terms of communication and contact, and hence more integrated with the state, or they may be more distant and hence more separated from the state. However, one should be aware that a form of 'nearness' does not necessarily entails a strong ideological affinity. Closeness thus refers to a situation in which government is willing to cooperate with each actor, avoiding the undue favoring of specific ideas. The second dimension ('independence') relates to finance and control, which would determine the nonprofit's dependence or independence from government. Measurements of control are usually attached to financing agreements. Still, in most western welfare states NPOs may be dependent upon public funding, this does not imply that they all suffer from heavy regulation. In that respect control and finance should best be dealt with as separate measures for organizational independence from government (Henriksen 2007).

[figure 1 here]

Combining both dimensions leads to four different positions (see figure 1). 'Integrated dependence' means that the organization heavily relies on government to obtain sufficient resources or faces strong control pressure, while it is also able to maintain close contacts with government officials. In case of 'separate dependence' the organization is still largely dependent on government monies (or it faces control measures), but it does not maintain close contacts with government officials. In a situation of 'integrated autonomy' the NPO does not receive significant financial support from government or faces only weak accountability pressure but still it is able to maintain its contacts with government officials. 
Finally, in case of 'separate autonomy' the organization is not dependent on government for funding or control measures while it does also not maintain close links with government officials. Figure 1 contains all four possible models of interaction between governments and NPOs as outlined by Kuhnle and Selle.

\section{Research method}

As it is this article's central aim to understand the nature of the relationship between NPOs and government through the use of a relational typology, we need an operationalization of some key concepts for field-testing. In our approach, more than 700 private nonprofit organizations were addressed, via a large-N survey, about their relationships with governments at the national (federal) level, the regional (Flemish) level and the local level. Our units of analysis are service-delivering NPOs active in four areas of current welfare policy in Flanders that received increased governmental attention in recent years: the field of poverty reduction, elderly care, youth care, and the integration of ethniccultural minorities. Having listed all organizations active in these service areas, we then started to further delineate our population. First, we limited ourselves to those organizations that have a permanent and formal character. This was reflected in the presence of paid staff. We recognize that purely voluntary organizations do play an important role in vitalizing contemporary civil societies. However, given the particular aim of this article (determining the relationships), we only selected the more professionalized service agencies that have been able to develop long-term relationships with policy makers. Second, the selected NPOs also have a private character. The fact that they receive large amounts of their income from public authorities may thus not prevent them from being self-governed as private entities. This implies that all public service providers in these areas were deleted from the population. Third, we only selected one particular legal type of organizations, the so-called "associations 
without for-profit motives" (known as VZWs-Verenigingen Zonder Winstoogmerk-in Flanders). This is the dominant legal form in the Flemish nonprofit sector (and especially in the domain of welfare) and implies that these organizations are legally bounded by the nondistribution constraint. Finally, we limited ourselves to organizations that are active in one of the 13 biggest cities in Flanders, being the Dutch-speaking region of Belgium. It is important to acknowledge that, especially in a densely populated region such as Flanders, these urban NPOs do not limit their activities to the city in which they are established but also perform a pivotal role in attracting and serving customers and citizens from surrounding areas as well. Furthermore, many of the societal issues dealt with in the selected policy domains, especially poverty reduction and the integration of ethnic-cultural minorities, are predominately typical urban phenomena in Flanders.

Following a pilot of 8 organizations, the survey was e-mailed to all the NPO executive (a CEO or director) in January 2010. Two weeks after the survey was launched we contacted respondents via a telephone reminder. This resulted in a total response rate of $35 \%$ (or 255 organizations). For a full overview of the composition of the research sample and the respective response rates in the four policy domains under study we refer to the table in annex 1.

The choice for choosing a one-side only NPO-oriented survey should not be problematic, as previous research indicates that it are mainly the NPOs that may have the lesser incentive to cooperate with local government, than vice versa. The reason is that most NPOs in our research population are financed and steered by the Flemish government, hence develop strong accountability relations with the Flemish regional government which is their principal governmental sparring partners. The fact that most NPOs are not, or only very little, financed by local governments, implies that local government has only few possibilities to incentivize NPOs to engage in their local social policy (Verschuere \& De Rynck 2010). For this reasons, surveying the NPOs' perceptions of their relations with local government is a valid 
approach to test the extent to which current practice is fertile ground to have the ideas of the Decree on Local Social Policy implemented.

In the process of developing the questionnaire, the typology of Kuhnle and Selle, but also empirical research based on this framework (Vincent and Harrow 2005; Henriksen 2007) was an important source of inspiration for translating these abstract concepts that underpin the framework into operational definitions and concrete questions intended to be meaningful for nonprofit executives in Flanders. According to their first dimension, Kuhnle and Selle suggest that the 'closeness' of an organization to the state relates to the scope, the frequency and easiness of the communication and contact. In our survey we asked respondents to indicate the frequency (or intensity) of the direct contacts their organizations have with policy makers at the local level. This resulted in two separate variables in which organizations got a score of 0 (rather not having direct contacts) or 1 (having direct lines of communication at most times). The first variable measured the amount of direct contacts with politicians at the local level, while the second one measured the amount of direct contacts with administrations (civil servants) at the local level. In order to obtain one unique variable that could help us to determine the nearness of each NPO to local policy makers (both politicians and administrations) we then recoded the original variables into a new variable with three categories. The first category represented the situation in which NPOs did not have any direct contacts, nor with politicians nor with administrations, at the local governmental level and thus are very separated from the state. The second category reflected the situation in which NPOs developed direct contacts with only one local policy maker (either politicians or either administrations). The third category represented a situation in which NPOs maintained direct contacts with both local politicians and local administrations. 
The second dimension of the typology relates to the 'independence' of the organizations from the state. According to Kuhnle and Selle organizations may be either autonomous or dependent vis-à-vis government in two different ways: in terms of financing and in terms of control. As it is argued that the financing and control actually reflect different aspects of the NPOs independence from the state, we will hold on to this difference in the remainder of this article (Henriksen 2007; Toepler 2010). The aspect of finance is measured as the amount of income that was provided by local government in the NPOs total budget. Respondents could position their organization into one of three categories presented to them. The first category consists of NPOs indicating that local government income does only represent a marginal share (less than 10\%) of their total budget. In that respect these organizations may operate autonomous from local government. A second category reflected a situation in which NPOs received a substantial part (more than $10 \%$ but less than $50 \%$ ) of their income from local government. We argue that these organizations are relatively dependent upon local government. The third category contains all NPOs to which local government is the dominant source of income (more than $50 \%$ of the total budget), implying large dependence.

The control-dimension is measured as the extent to which NPOs must adhere to a set of accountability parameters imposed by local government. In concrete, we asked respondents to indicate whether or not (score 0 or 1 ) they must adhere to the following accountability parameters imposed by local government in the municipality in which they were active: the need to provide reports on the financial performance of the NPO; the obligation to follow specified administrative procedures; requirements to ensure the quality of the services the NPO delivers; requirements about the quantity (number of services) of the NPOs service delivery; demands for serving specific groups within civil society (target audience); and finally the need to obtain social effects through their service delivery (e.g. reducing poverty, etc.). We then constructed a new variable that reflects the relative degree of control exerted by 
local government. As was the case for the other two key variables of our framework, this variable consists of three categories. Looking at this particular control dimension the first category contains all NPOs that are held accountable by local government on maximum one out of six parameters. In that respect one could argue that these NPOs are able to maintain their autonomy. The second category consists of those organizations held accountable by two to four (on a total of six) of the above accountability parameters. The third category contains NPOs that have to adhere to at least five or even all six accountability parameters presented to them, implying large dependence towards local government.

\section{Results: measuring local government - NPO relations}

Using crosstabs we combine the variable of nearness (contact) with the variables of the NPOs' financial independence (finance) from local government, and the accountability pressure (control) exerted by local government on NPO's.

Table $1^{1}$ shows that $20 \%$ of all organizations in our sample do not receive substantial income (less than $10 \%$ of their total income) from local government, while also being separated from local government in terms of communication and contacts. This reflects a situation of separate autonomy. We notice that almost half of the NPOs in this group (14 out of 29) are active in youth care (Y). We also observe that $26 \%$ of the organizations combines poor financial ties to local government with very high levels of contact with local policy makers (both administrations and politicians). This reflects a situation of

\footnotetext{
${ }^{1}$ From the 255 organisations that responded to our survey, 140 can be used for our analyses. This reduced number of organisations is due to the fact that organisations that have a missing value on one of the key variables for this study have been left out of the analyses.
} 
integrated autonomy. About one third of both the elderly care organizations (E: 9 out of 25) and the organizations for ethnic-cultural minorities (M: 8 out of 22) belong to this category.

[Table 1 Here]

Within the group of NPOs that is heavily dependent on local government income $(\mathrm{N}=16)$ we see that almost all of these organizations (14 out of 16) also maintains close contacts with local social policy makers. Or, in other words, exactly $10 \%$ of all NPOs in our sample could be assigned to a situation of integrated dependence. More than half of the NPOs in this group (8 out of 14) is active in youth care. Next, there were no organizations that combined a significant amount of local government income (more than $50 \%$ of their total budget) and low levels of communication and contact with local policy makers (situation of separate dependence).

Still, there are two clusters of NPOs in table 1 that deserve some further attention. First, we witness a relatively large group of 31 NPOs ( $22 \%$ of our total sample) that have very little financial ties with local government, but still are relatively close either with local politicians or local administrations. We notice that this category contains organizations from all four policy domains under study. Second, there is a group of 23 NPOs (16\% of the total sample) that have very close contacts with both local policy makers while also being relatively dependent on local government (between 10 and $50 \%$ of their budget) for their financing. This seems especially to be the case for poverty organizations $(P)$ which represent the largest share (17 out of 23 ) within this category. 
Table $2^{2}$ shows that 24 NPOs ( $16 \%$ of our sample) do not maintain close contacts with local policy makers, neither with politicians nor with administrations, while also not facing high levels of government control (separate autonomy). Half of the NPOs in this group (12 out of 24) are active in youth care. Next, 21 organizations (or $14 \%$ of the sample) are in a situation in which they do not face strong control from local government, but are still able to maintain close contacts with local policy makers (integrated autonomy). More than one third ( 8 out of 22) of the organizations that are active in the integration of ethnic-cultural minorities does belong to this category. Concerning the situation of separate dependence, we found only very little (approximately $1 \%$ of the sample) empirical support for the existence of this category in Flanders. Next, 36 organizations in our sample (25\%) could be assigned to the category of integrated dependence as they are strongly controlled or held accountable by local government, and at the same time also maintaining very close contacts with local policy makers. This seems to be especially the case for organizations active in reducing poverty and the group of NPOs that works with disadvantaged youth.

[Table 2 Here]

Finally, when looking at the in-between positions, we see that $13 \%$ of all NPOs are not controlled by local government, but still are relatively close to local politicians or to local administrations. We also notice that 23 organizations ( $15 \%$ of our sample) is relatively dependent upon local government in terms of control while also maintaining very close contacts with local politicians and local administrations. The largest share within this group (14 out of 23 ) does belong to the poverty policy domain.

\footnotetext{
${ }^{2}$ From the 255 organisations that responded to our survey, 145 can be used for our analyses. This reduced number of organisations is due to the fact that organisations that have a missing value on one of the key variables for this study have been left out of the analyses.
} 
All the results taken together, we can conclude that there are large variations between Flemish NPOs in terms of their relationships with local government: we can observe cases in the situations of separate autonomy, integrated autonomy and integrated dependence, in terms of Kuhnle and Selle's typology. This observation concurs with the findings of Henriksen (2007), who describes cases in all four possible positions of the typology, but who simultaneously argues that many of the Danish organizations in his study are moving in the direction of more nearness and dependence towards government. Also in our case, we observe that a majority of the NPOs are rather close to local government in terms of their contacts with local politicians and civil servants. Jeremy Vincent and Jenny Harrow (2005), using surveydata of Scottish and English NPOs in the field of health, observed that almost three out of four English organizations considered themselves as being independent from central government. Scottish respondents were more divided, with almost half of the NPOs considering themselves as rather dependent upon central government. Also, nearly three quarters of both Scottish and English NPOs reported a perception of nearness to central government. These figures are rather similar to what we observe for the Flemish case, with most NPOs in a situation of 'integration', with varying levels of dependence on local government. Contrary to the Flemish, Danish and English and Scottish cases, Kolaric and Rakar (2007) observed for the Slovenian case that, at a sectoral level, the relationship between the nonprofit sector and government could still mainly be classified as a situation of separate autonomy.

\section{Discussion \& conclusion}

We conclude with a discussion on (1) the empirical findings (first research question) which also enable us to refine the original typology, and (2) the policy relevance of our findings (second research question). 
A refined typology for systematizing empirical results

We acknowledge that this study has its limitations. We are aware that we only surveyed 'one side' (NPO executives), although we argued that this choice is valid for our research purposes. Our approach to the topic offers a good starting point to study some of the key aspects of the relationships private nonprofit organizations develop with governments in contemporary welfare states. Our approach allows us to analyze data from a large sample of NPOs, and to make some descriptive statements about how the field of NPOs in the Flemish welfare sector interacts with government.

Although the results presented in table 1 and table 2 are not completely similar, which is due to the fact that organizational dependence was measured in two ways (financing and control, see also Henriksen 2007), we observe a comparable distribution of cases in both tables. As a result, our research enables us to add some refinements to the original framework of Kuhnle and Selle. Having used variables (contact, finance and control) that consist of three positions instead of two positions in the initial typology, and having combined these variables (contact vs. finance and contact vs. control), enables us to propose a typology with nine positions (see figure 2). Our evidence shows that most Flemish NPOs situate themselves in five positions of the refined typology: integrated dependence, integrated autonomy, semi-integrated autonomy and integrated semi-autonomy and separate autonomy.

[Figure 2 here]

Respectively 74 out of 140 (table 1) and 80 out of 140 (table 2) of the NPOs under study are able to maintain very close contacts with local social policy makers. This implies that more than half of all 
Flemish NPOs under study are already well-integrated with local government, through the use of regular contacts and communication with both local politicians and local administrations. Still, we can differentiate in this group of well-integrated NPOs by looking at the extent to which they are dependent on local government (financially, or in terms of control): some are very autonomous, while others are very dependent. Another cluster of NPOs (approximately $15 \%$ of our sample) that are very integrated with local government, are only 'relatively' dependent upon local funding or control pressure exerted by local government. We could call this a position of 'integrated semi-autonomy' (see figure 2). This implies that NPOs develop close relationships and contacts with local policy makers, but equally have to attribute organizational time and effort to deal with other governmental levels that are important sources of financing (mostly but not always the regional Flemish government).

Furthermore, we notice that a relatively large group of organizations does not develop any relationship at all with local government. The majority of this group is in a position of separate autonomy: being not dependent on government in terms of finance and control, and having no contacts with the local governmental level. Finally, one group of NPOs are very autonomous from local government, but still develop relatively close contacts with local politicians or local administrations. We could call this position 'semi-integrated autonomy' (see figure 2). We could thus argue that the absence of a financial (or control) relationship does not necessarily entails the absence of all communication and contact between NPOs and local government.

The other three positions in the typology that were added in comparison with the original Kuhnle and Selle typology - which we call separate semi-autonomy, semi-integrated semi-autonomy and semiintegrated dependence (see figure 2) - are mainly theoretical, as we hardly observe NPOs in these positions (at least in our case). 
When comparing NPOs belonging to the four different policy domains, we see that most organizations that are active in elderly care find themselves in a position of independence towards local government. Still, in the group of elderly care organizations, and despite the independence from local government, there is variation what the contacts with local government is concerned. Also many youth care organizations seems to be independent from local government as they receive very little financial support and face low control pressures. But also here, we observe variation in terms of contacts with local government. This position should not surprise, as we know that NPOs in youth care and elderly care mainly develop an organizational focus towards a higher governmental (e.g. the regional Flemish) level: they are mainly financed and controlled by the federal and regional (Flemish) government. This can reduce the local government's capacity and legitimacy to urge these NPOs to also invest in developing additional relationships at the local governmental level, which explains that some of these NPOs are in a situation of 'separate autonomy'. In the case of special youth there is also the scale of operations that explains the lesser bonds with local government: NPOs in youth care often work on a scale that is larger than the scale of the local government, serving young people from a larger region than the municipality in which the NPO is located.

Organizations in the other two policy domains under study in this article, fighting poverty and the integration of ethnic-cultural minorities, are reporting significant higher levels of integration and cooperation with local government, even if they are not always fully dependent upon local government in terms of finance and control. Especially organizations within the poverty policy domain report very close contacts and open lines of communication with local policy makers. For the group of organizations active in the integration of ethnic-cultural minorities we see that a substantial part reports very close contacts while also maintaining their autonomy from local government (integrated autonomy). This 
could be explained by the fact that, especially in larger municipalities (which are the scope of this article), these policy domains could be seen as politically salient policy fields (poverty and integration of ethnic minorities), making it more logical and necessary for both NPOs and local governments to establish a form of cooperation in solving day-to-day needs. As a matter of fact, hardly any organization was observed in the situation of 'separate dependence'.

Implications for the implementation of central governmental policy towards local government - NPO cooperation

The fact that we rely on survey-data derived from a standardized questionnaire may limit our understanding of the dynamics of local government-NPO interactions. We acknowledge that we do not offer results of longitudinal research, which makes testing the effect of the Decree (central government) on local policy practice (NPO - local government cooperation) not possible. We can, however, add to the discussion by looking at the circumstances of current (perception of) practice of NPO-government relations, and thus make some statements about the likelihood that the ideas of central governmental policy initiatives will be reflected in the local practice, or not.

As discussed above, the Decree on Local Social Policy (2004) aims at maximizing accessibility of social service delivery to citizens at the local, and hence closest, governmental level by establishing a strong cooperation between NPOs and local government in every municipality. Starting from their coordinating role, local governments must thus establish a process of interaction, information exchange and sufficient levels of communication. In terms of Kuhnle and Selle, this would imply the establishment of a relative degree of integration with service delivering NPOs active on their territory. We found that this integration (in terms of contacts between NPOs and local decision-makers) is quite well developed for 
most NPOs, despite the fact that local governments often lack the means (mainly financial) to offer incentives for NPOs to be engaged in their local social policy (Verschuere \& De Rynck 2010, cf. also supra). Whether this large integration is the result of the prescriptions of the Decree is not clear however: NPOs and local governments may have other incentives to cooperate, like mutual dependence in politically salient fields for example. However, based on our findings, we can conclude that current practice of NPO-local government relations at least offers some fertile grounds for increasing the engagement of NPOs in local social policy in Flanders. According to our data, most NPOs perceive their relation with local government as being 'near' (having contacts with administrative and/or political local decision-makers). The fact that most NPOs are not dependent on local government for their financial resources, however, may continue to be a serious impediment to be engaged, as there are few possibilities for local governments to financially incentivize NPOs to cooperate in local social policy. We found that as soon as Flemish NPOs receive public funding from local government, albeit a relatively small part of their total budget, and face the control measures attached to these funds, these NPOs also start to establish and maintain contacts with local government.

\section{References}

Amirkhanyan, A. A., H. J. Kim, et al. (2012). "Closer Than "Arms Length": Understanding the Factors Associated With Collaborative Contracting." American Review of Public Administration 42(3): 341-366.

Anheier, L. (2005). The Nonprofit Sector: Approaches, Management, Policy. New York, Routlegde.

Balassiano, K. and S. M. Chandler (2010). "The Emerging Role of Nonprofit Associations in Advocacy and Public Policy: Trends, Issues, and Prospects." Nonprofit and Voluntary Sector Quarterly 39(5): 946-955. 
Benjamin, L. (2008). "Account space: How accountability requirements shape nonprofit practice." Nonprofit and Voluntary Sector Quarterly 37.

Binderkrantz, A. (2005). "Interest group strategies: Navigating between privileged access and strategies of pressure." Political Studies 53(4): 694-715.

Brinkerhoff, J. M. (2002). Government-nonprofit partnership: A defining framework, Public Administration Dev.

Child, C. D. and K. A. Gronbjerg (2007). "Nonprofit advocacy organizations: Their characteristics and activities." Social Science Quarterly 88(1): 259-281.

Coston, J. M. (1998). "A model and typology of Government-NGO relationships." Nonprofit and Voluntary Sector Quarterly 27(3): 358-382.

De Rynck, F., B. Verschuere, et al. (2009). Re-thinking the state: critical perspectives on the citizen, politics and government in the 21st century. Mechelen, Kluwer.

Defourny, L. and Pestoff (2008). Images and concepts of third sector in Europe. Working Paper no.08/02, EMES European Research Network.

DiMaggio, P. and W. Powell (1991). The new institutionalism in organizational analysis. Chicago, University of Chicago Press.

Dörner, L. (2008). A tool for charting out the relationships between government and third sector organizations in various national settings. ISTR/EMES/CINEFOGO Conference: The Third Sector and Sustainable Social Change: New Frontier for research. Barcelona.

Gazley, B. (2010). "Why Not Partner With Local Government? Nonprofit Managerial Perceptions of Collaborative Disadvantage." Nonprofit and Voluntary Sector Quarterly 39(1): 51-76.

Henriksen, L. (2007). "The diversity of government-nonprofit relations - Selected cases from Danish Social Policy." Paper Presented at IRSPM panel on 'Comparative perspectives on the government-nonprofit relationship (Potsdam, Germany). 
Kearns, L. (1996). Managing for accountability: Preserving the public trust in public and nonprofit organizations, Jossey-Bass San Francisco.

Klijn, E. H., B. Steijn, et al. (2010). "The impact of network management on outcomes in governance networks." Public Administration 88(4): 1063-1082.

Kolaric, Z. and T. Rakar (2007). The role of civil society organizations in the service provision and governance in the framework of the Slovene welfare system. CINEFOGO. Berlin.

Kramer, L. (1981). Voluntary agencies in the welfare state, University of California Press Berkeley.

Kuhnle and Selle (1990). "Meeting needs in welfare state: relations between government and voluntary organizations in Norway." In: Needs and welfare / Ed. by Alan Ware and Robert E. Goodin: 165184.

Mandell, M. and R. Keast (2011). Strategic leveraging: A revised framework of managing strategically in collaborative networks. 7th TAD. Newark (New Jersey).

May (2007). "Regulatory Regimes and accountability." Regulation and governance 1.

McCarthy, J. and M. Zald (1977). "Resource mobilization and social movements: A partial theory." American Journal of Sociology 82(6).

McLaughlin, L. and Osborne (2003). "Modeling the Challenge of changing institutional relationships between government and the voluntary sector in the UK." Asian Journal of Public Administration 25(1): pp.5-30.

Mosley, J. E. (2011). "Institutionalization, Privatization, and Political Opportunity: What Tactical Choices Reveal About the Policy Advocacy of Human Service Nonprofits." Nonprofit and Voluntary Sector Quarterly 40(3): 435-457.

Najam, L. (2000). "The Four C's of Third Sector-Government Relations. Cooperation, Confrontation, Complementarity and co-optation." Nonprofit Management and Leadership 10(4): pp. 375-397. 
Ospina, L., Diaz, et al. (2002). "Negotiating accountability: Managerial lessons from identity-based nonprofit organizations." Nonprofit and Voluntary Sector Quarterly 31.

Pfeffer, J. and G. Salancik (2003). The external control of organizations: A resource dependence perspective (2nd ed.). Stanford, CA, Stanford University Press.

Powell, W. (1987). The nonprofit sector: A research handbook. New Heaven, CT, Yale University Press.

Putnam, R. A. (2000). "Democracy without foundations." Ethics 110(2): 388-404.

Putnam, R. D. (1995). "BOWLING ALONE, REVISITED." Responsive Community 5(2): 18-33.

Ross and Osborne (1999). "Making a reality of community governance. Structuring governmentvoluntary sector relationships at the local level." Public Policy and Administration 14(49): 49-61.

Salamon, L. (1995). Partners in Public Service: Government-nonprofit relations in the modern welfare state. Baltimore, John Hopkins University Press.

Salamon, L., Anheier, et al. (1999). Global Civil Society: Dimensions of the Nonprofit sector.

Salamon, L., Sokolowski, et al. (2004). Global Civil Society: Dimensions of the nonprofit sector. Bloomfield, Kumarian Press.

Salamon, L. M. (1987). "Of market failure, voluntary failure and 3rd-party government: Toward a theory of government-nonprofit relations in the modern welfare-state." Journal of Voluntary Action Research 16(1-2): 29-49.

Sawer, M. (2002). "Governing for the mainstream: Implications for community representation." Australian Journal of Public Administration 61(1): 39-49.

Schneider, J. A. (2009). "Organizational Social Capital and Nonprofits." Nonprofit and Voluntary Sector Quarterly 38(4): 643-662.

Smith, L. and Lipsky (1993). "Nonprofits for hire: The welfare state in the age of contracting." Cambridge, MA, Harvard University Press: In: Anheier (2005), Nonprofit Organizations: Theory, Management, Policy. 
Snavely, K. and U. Desai (2001). "Mapping local government-nongovernmental organization interactions: A conceptual framework." Journal of Public Administration Research and Theory 11(2): 245-263.

Suarez, D. F. (2011). "Collaboration and Professionalization: The Contours of Public Sector Funding for Nonprofit Organizations." Journal of Public Administration Research and Theory 21(2): 307-326.

Toepler, S. (2010). Government dependency on nonprofits: a review of the evidence and proposal for a new conceptual framework. ISTR. Istanbul.

VanSlyke, L. (2007). "Agents or Stewards: using theory to understand the government-nonprofit social service contracting relationship." Journal of Public Administration Research and Theory 17.

Verschuere and D. Rynck (2010). Directing without power, governing without strength? Cooperation between local government and the private sector. ECPR. Munster.

Vincent and Harrow (2005). "Comparing thistles and roses: the application of governmental-voluntary sector relations theory to Scotland and England." International Journal of Voluntary and Nonprofit Organizations 16(4): 375-395.

Wang, S. (2006). "Money and autonomy: patterns of civil society finance and their implications." Studies in Comparative International Development 40(4): 3-29.

Whitaker, G. P., L. Altman-Sauer, et al. (2004). Mutual accountability between governments and nonprofits - moving beyond "surveillance" to "service", Sage Publications Inc.

Young, D. R. (2000). "Alternative models of government-nonprofit sector relations: Theoretical and international perspectives." Nonprofit and Voluntary Sector Quarterly 29(1): 149-172.

Zimmer, A. (2010). Third Sector-Government Partnerships Third Sector Research. R. Taylor, Springer New York: 201-217. 
2

6

7

8

9

10

11

12

13

14

15

16

17

18

19

20

21

22

23

24

25

26

27

28

29

30

31

32

33

34

35

36

37

38

39

40

41

42

43

44

45

46

47

48

49

50

51

52

53

54

55

56

57

58

59

60
Figure 1 - Typology of government-nonprofit relationships (Kuhnle and Selle 1990)

\begin{tabular}{|l|l|c|c|}
\hline \multicolumn{2}{|c|}{} & \multicolumn{2}{c|}{ In terms of communication and contact } \\
\cline { 3 - 4 } \multicolumn{2}{|c|}{} & DISTANCE & NEARNESS \\
\hline \multirow{2}{*}{$\begin{array}{l}\text { In terms of finances } \\
\text { and control }\end{array}$} & INDEPENDENCE & Separate autonomy & Integrated autonomy \\
& & & \\
\cline { 3 - 4 } & DEPENDENCE & Separate dependence & Integrated dependence \\
\hline
\end{tabular}

25

URL: http://mc.manuscriptcentral.com/rpxm Email: Isobel.speedman@ed.ac.uk 
Figure 2 - New typology of government-nonprofit relationships

\begin{tabular}{|c|c|c|c|c|}
\hline & & \multicolumn{3}{|c|}{ In terms of communication and contact } \\
\hline & & LARGE DISTANCE & $\begin{array}{l}\text { INTERMEDIATE } \\
\text { DISTANCE }\end{array}$ & SMALL DISTANCE \\
\hline \multirow{3}{*}{$\begin{array}{l}\text { In terms of } \\
\text { finances and } \\
\text { control }\end{array}$} & INDEPENDENCE & Separate autonomy & $\begin{array}{c}\text { Semi-integrated } \\
\text { autonomy }\end{array}$ & Integrated autonomy \\
\hline & $\begin{array}{l}\text { INTERMEDIATE } \\
\text { (IN)DEPENDENCE }\end{array}$ & $\begin{array}{c}\text { Separate semi- } \\
\text { autonomy }\end{array}$ & $\begin{array}{c}\text { Semi-integrated semi- } \\
\text { autonomy }\end{array}$ & $\begin{array}{l}\text { Integrated semi- } \\
\text { autonomy }\end{array}$ \\
\hline & DEPENDENCE & Separate dependence & $\begin{array}{l}\text { Semi-integrated } \\
\text { dependence }\end{array}$ & Integrated dependence \\
\hline
\end{tabular}

URL: http://mc.manuscriptcentral.com/rpxm Email: Isobel.speedman@ed.ac.uk 
Table 1 - Relations of Flemish NPOs to local governments in terms of contacts and amount of income (scores for total sample and for each of the four policy domains under study)

\begin{tabular}{|c|c|c|c|c|c|c|c|c|c|c|c|c|c|c|c|}
\hline \multirow{5}{*}{\multicolumn{3}{|c|}{$\begin{array}{l}\text { P=poverty (N=51) } \\
E=\text { elderly care }(N=25) \\
Y=\text { youth care }(N=42) \\
M=\text { ethnic-cultural minorities }(N=22)\end{array}$}} & \multicolumn{12}{|c|}{ NEARNESS } & \multirow[b]{3}{*}{ Total } \\
\hline & & & \multicolumn{12}{|c|}{ Frequency of contacts with local policy makers ( 3 catg) } & \\
\hline & & & \multicolumn{4}{|c|}{$\begin{array}{l}\text { NPO is separated from } \\
\text { local government (no } \\
\text { contacts with local } \\
\text { politicians and } \\
\text { administrations) }\end{array}$} & \multicolumn{4}{|c|}{$\begin{array}{l}\text { NPO is relatively close } \\
\text { to local government } \\
\text { (having contacts with } \\
\text { local politicians or local } \\
\text { administrations, but } \\
\text { not with both) }\end{array}$} & \multicolumn{4}{|c|}{$\begin{array}{l}\text { NPO is very close to } \\
\text { local government } \\
\text { (contacts with both local } \\
\text { politicians and local } \\
\text { administrations }\end{array}$} & \\
\hline & & & \multicolumn{4}{|c|}{$\begin{array}{l}\mathrm{N} \text { (and \%) in total } \\
\text { sample }\end{array}$} & \multicolumn{4}{|c|}{$\begin{array}{l}\mathrm{N} \text { (and \%) in total } \\
\text { sample }\end{array}$} & \multicolumn{4}{|c|}{$\begin{array}{c}\mathrm{N} \text { (and \%) in total } \\
\text { sample }\end{array}$} & \\
\hline & & & $\mathbf{P}$ & $E$ & $Y$ & $M$ & $\mathbf{P}$ & E & $Y$ & M & $\mathbf{P}$ & $E$ & $Y$ & M & \\
\hline \multirow{2}{*}{$\begin{array}{l}\mathbf{D} \\
\mathbf{E} \\
\mathbf{P}\end{array}$} & \multirow{6}{*}{$\begin{array}{l}\text { Amount of } \\
\text { income from } \\
\text { local } \\
\text { government }\end{array}$} & \multirow{2}{*}{$\begin{array}{l}\text { NPO is not dependent at all } \\
\text { on local government }(<10 \% \\
\text { of total budget) }\end{array}$} & \multicolumn{4}{|c|}{$29(20 \%)$} & \multicolumn{4}{|c|}{$31(22 \%)$} & \multicolumn{4}{|c|}{$37(26 \%)$} & \multirow[t]{2}{*}{97} \\
\hline & & & 3 & 8 & 14 & 4 & 10 & 8 & 9 & 4 & 12 & 9 & 8 & 8 & \\
\hline $\begin{array}{l}\mathrm{E} \\
\mathbf{N} \\
\mathbf{D}\end{array}$ & & \multirow[t]{2}{*}{$\begin{array}{l}\text { NPO is relatively dependent } \\
\text { on local government (10- } \\
50 \% \text { of total budget) }\end{array}$} & \multicolumn{4}{|c|}{$1(0,9 \%)$} & \multicolumn{4}{|c|}{$3(3 \%)$} & \multicolumn{4}{|c|}{$23(16 \%)$} & 27 \\
\hline \multirow{3}{*}{$\begin{array}{l}\mathrm{E} \\
\mathrm{N} \\
\mathrm{C} \\
\mathrm{E}\end{array}$} & & & 1 & 0 & 0 & 0 & 2 & 0 & 0 & 1 & 17 & 0 & 3 & 3 & \\
\hline & & $\begin{array}{l}\text { NPO is heavily dependent on } \\
\text { local government }(>50 \% \text { of }\end{array}$ & \multicolumn{4}{|c|}{$0(0,0 \%)$} & \multicolumn{4}{|c|}{$2(2 \%)$} & \multicolumn{4}{|c|}{$14(10 \%)$} & 16 \\
\hline & & & 0 & 0 & 0 & 0 & 2 & 0 & 0 & $\circ$ & 4 & 0 & 8 & 2 & \\
\hline & Total & & \multicolumn{4}{|c|}{30} & \multicolumn{4}{|c|}{36} & \multicolumn{4}{|c|}{74} & 140 \\
\hline
\end{tabular}


Table 2 - Relations of Flemish NPOs to local governments in terms of contacts and control pressure (scores for total sample and for each of the four policy domains under study)

\begin{tabular}{|c|c|c|c|c|c|c|c|c|c|c|c|c|c|c|c|}
\hline & & & & & & & & $\Delta R$ & :SS & & & & & & \\
\hline & & & & & que & of $c$ & tact & ith & $\mathrm{al} p c$ & y ma & ers (3 & atg) & & & \\
\hline & $\begin{array}{l}\text { verty ( } \mathrm{N}=57) \\
\text { lerly care }(\mathrm{N}=2 \\
\text { uth care }(\mathrm{N}=42 \\
\text { hnic-cultural } \mathrm{m}\end{array}$ & orities ( $\mathrm{N}=\mathbf{2 2}$ ) & $\begin{array}{l}\text { NPC } \\
\text { loca } \\
\text { con } \\
\text { poli } \\
\text { adn }\end{array}$ & $\begin{array}{l}\text { sepa } \\
\text { over } \\
\text { ts wi } \\
\text { ans } \\
\text { strat }\end{array}$ & $\begin{array}{l}\text { ent } \\
\text { ocal }\end{array}$ & & $\begin{array}{l}\text { NP } \\
\text { to I } \\
\text { (ha } \\
\text { loc } \\
\text { adr } \\
\text { not }\end{array}$ & $\begin{array}{l}\text { l gc } \\
\text { g cc } \\
\text { olit } \\
\text { istr } \\
\text { th }\end{array}$ & $\begin{array}{l}\text { nm } \\
\text { ats } \\
\text { ns C } \\
\text { ns, }\end{array}$ & & $\begin{array}{l}\text { NPC } \\
\text { loca } \\
\text { (cor } \\
\text { loca } \\
\text { loca }\end{array}$ & $\begin{array}{l}\text { sov } \\
\text { acts } \\
\text { ooli } \\
\text { adm }\end{array}$ & $\begin{array}{l}\text { clos } \\
\text { nme } \\
\text { vith b } \\
\text { ians } \\
\text { istra }\end{array}$ & & Total \\
\hline & & & & $\begin{aligned} \text { (anc } & \\
\text { Se } & \end{aligned}$ & le & & & and & $\begin{array}{l}\text { in } t \\
\text { le }\end{array}$ & & & $\begin{array}{l}\text { ind } \\
\text { sa }\end{array}$ & $\begin{array}{l}\text { ) in t } \\
\text { ple }\end{array}$ & & \\
\hline & & & $\mathbf{P}$ & E & $Y$ & $M$ & $\mathbf{P}$ & E & $Y$ & M & $\mathbf{P}$ & E & $Y$ & M & \\
\hline & & $\begin{array}{l}\text { NPO is autonomous from } \\
\text { local government in terms of }\end{array}$ & & & & & & & & & & & $4 \%)$ & & 65 \\
\hline $\begin{array}{l}E \\
P\end{array}$ & $\begin{array}{l}\text { Level of } \\
\text { control }\end{array}$ & & 1 & 8 & 12 & 3 & 3 & 7 & 9 & 1 & 5 & 4 & 4 & 8 & \\
\hline $\begin{array}{l}\text { E } \\
\text { N } \\
\text { D }\end{array}$ & $\begin{array}{l}\text { exerted by } \\
\text { local } \\
\text { government }\end{array}$ & $\begin{array}{l}\text { NPO is relatively dependent } \\
\text { on local government in } \\
\text { terms of control measures }\end{array}$ & & & & & & & & & & & $5 \%)$ & & 33 \\
\hline $\begin{array}{l}\mathrm{E} \\
\mathrm{N}\end{array}$ & $\begin{array}{l}\text { by imposing a } \\
\text { set of }\end{array}$ & & 2 & 0 & 1 & 0 & 5 & 0 & 0 & 2 & 14 & 3 & 2 & 4 & \\
\hline E & $\begin{array}{l}\text { accountability } \\
\text { parameters }\end{array}$ & $\begin{array}{l}\text { NPO is heavily dependent on } \\
\text { local government in terms of }\end{array}$ & & & & & & & & & & & $5 \%)$ & & 47 \\
\hline & & & 1 & 0 & 0 & 1 & 6 & 1 & 1 & 1 & 20 & 1 & 13 & 2 & \\
\hline & Total & & & & & & & & & & & & & & 145 \\
\hline
\end{tabular}




\section{Annex}

Annex 1 - Composition of research sample of Flemish NPOs

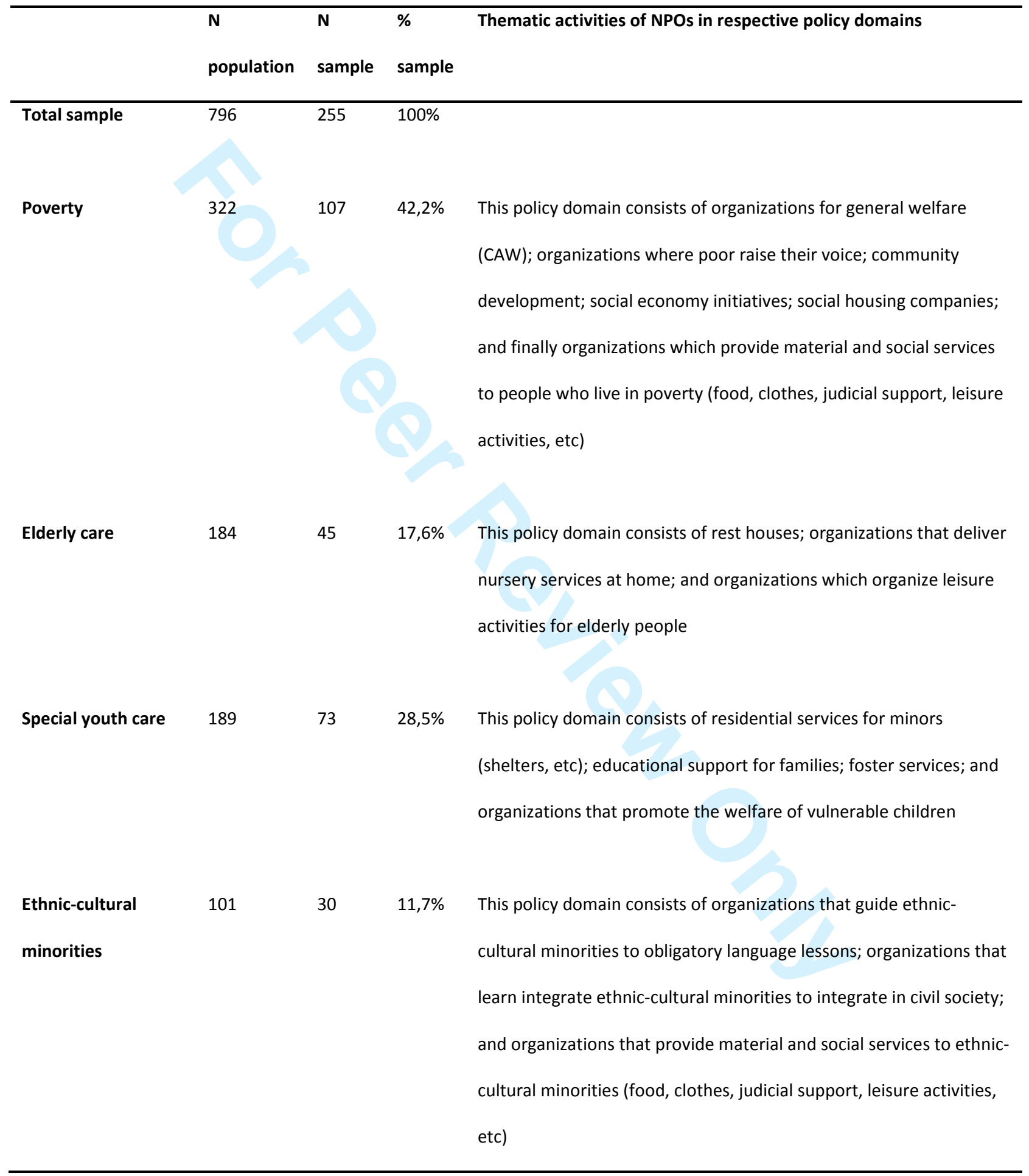

